\title{
Phylogenetic and biochemical characterization of a novel cluster of intracellular fungal $\alpha$-amylase enzymes
}

\section{Correspondence \\ M. J. E. C. van der Maarel \\ m.j.e.c.van.der.maarel@rug.nl}

Received 30 March 2007

Revised 21 June 2007

Accepted 10 July 2007
R. M. van der Kaaij,, ${ }^{1,2}$ Š. Janeček, ${ }^{3}$ M. J. E. C. van der Maarel ${ }^{1,2,4}$
and L. Dijkhuizen ${ }^{1,2}$

\author{
${ }^{1}$ Microbial Physiology Research Group, Groningen Biomolecular Sciences and Biotechnology \\ Institute (GBB), University of Groningen, The Netherlands \\ ${ }^{2}$ Centre for Carbohydrate Bioprocessing, TNO-University of Groningen, Haren, The Netherlands \\ ${ }^{3}$ Institute of Molecular Biology, Slovak Academy of Sciences, Bratislava, Slovakia \\ ${ }^{4}$ Business Unit Food and Biotechnology Innovations, TNO Quality of Life, Groningen, The \\ Netherlands
}

\begin{abstract}
Currently known fungal $\alpha$-amylases are well-characterized extracellular enzymes that are classified into glycoside hydrolase subfamily $\mathrm{GH} 13$ _1. This study describes the identification, and phylogenetic and biochemical analysis of novel intracellular fungal $\alpha$-amylases. The phylogenetic analysis shows that they cluster in the recently identified subfamily $\mathrm{GH} 13$ _5 and display very low similarity to fungal $\alpha$-amylases of family GH13_1. Homologues of these intracellular enzymes are present in the genome sequences of all filamentous fungi studied, including ascomycetes and basidiomycetes. One of the enzymes belonging to this new group, Amy $1 p$ from Histoplasma capsulatum, has recently been functionally linked to the formation of cell wall $\alpha$-glucan. To study the biochemical characteristics of this novel cluster of $\alpha$-amylases, we overexpressed and purified a homologue from Aspergillus niger, AmyD, and studied its activity product profile with starch and related substrates. AmyD has a relatively low hydrolysing activity on starch $\left(2.2 \mathrm{U} \mathrm{mg}^{-1}\right)$, producing mainly maltotriose. A possible function of these enzymes in relation to cell wall $\alpha$-glucan synthesis is discussed.
\end{abstract}

\section{INTRODUCTION}

$\alpha$-Amylases are widely occurring enzymes which hydrolyse the $\alpha-(1,4)$-glycosidic bonds in starch and glycogen, producing short maltooligosaccharides and maltose. Based on sequence similarity, most $\alpha$-amylases (EC 3.2.1.1) are classified in glycoside hydrolase (GH) family 13 , although some $\alpha$-amylases originating from extremophilic organisms belong to family GH57 (Henrissat, 1991; Henrissat \& Bairoch, 1996) (see also the CAZy website, http://www.cazy.org). Based on a phylogenetic analysis of 1691 different members of the GH13 family, the family has recently been divided into 35 subfamilies, all acting on $\alpha$ glycosidic bonds (Stam et al., 2006). Several of these subfamilies display $\alpha$-amylase specificity, but many other enzyme reaction specificities are also represented. The tertiary structure of these enzymes is characterized by a $(\beta / \alpha)_{8}$ barrel containing four highly conserved amino acid regions that form the active site (MacGregor et al., 2001), but the overall sequence similarity can be as low as $10 \%$ and only a catalytic triad of amino acids is conserved

Abbreviations: GH, glycoside hydrolase; GPI, glycosylphosphatidylinositol. invariantly (Machovic \& Janecek, 2003). The shared $(\beta / \alpha)_{8}$ barrel structure and catalytic mechanism within GH13 enzymes are believed to represent a common evolutionary origin (Kuriki \& Imanaka, 1999; Janecek, 1997). The presence of the four conserved regions and a common secondary and tertiary structure allow construction of alignments and phylogenetic studies within the family. The phylogeny of $\alpha$-amylases is generally in agreement with their origin, e.g. all fungal $\alpha$-amylases are more related to each other than to the $\alpha$-amylases originating from plants or animals. $\alpha$-Amylases from bacteria, however, are scattered over several clusters, which group with animal, plant or fungal $\alpha$-amylases, or form a separate branch (Janecek, 1994).

Several $\alpha$-amylases from yeasts and fungi have been studied previously (see e.g. Steyn et al., 1995; Matsuura et al., 1984; Moreira et al., 2004; Boel et al., 1990). In all cases, these enzymes are secreted into the extracellular environment, where they are involved in degradation of starch and glycogen into small oligosaccharides, which can be imported into the cells to serve as energy and carbon sources. The expression levels of extracellular starch-degrading enzymes 
are generally increased during growth in the presence of maltose or isomaltose. This system is particularly well studied in aspergilli, in which expression of these enzymes is regulated by AmyR (Petersen et al., 1999; Tani et al., 2001; Nakamura et al., 1997).

Some recent studies have shown that different fungal GH13 enzymes may be involved in formation and/or modification of $\alpha$-glucans in fungal cell walls, rather than in starch degradation. The fungal cell wall is usually made up of chitin, $\beta$-glucan, $\alpha$-glucan, galactomannan and attached cell wall proteins (Klis et al., 2002; Beauvais \& Latgé, 2001). Generally, $\alpha$-glucan in fungal cell walls is of the $\alpha$-(1,3) type with a small percentage of $\alpha$ - $(1,4)$ glycosidic bonds (Grün et al., 2005). Additionally, an $\alpha$-glucan with alternating $\alpha$ $(1,3) /(1,4)$ glycosidic bonds (nigeran) has been identified in Aspergillus niger and some other ascomycete species (Barker \& Carrington, 1953; Woranovicz-Barreira et al., $1999)$. It is generally believed that these fungal $\alpha$-glucans are produced by $\alpha$-glucan synthases, although this has never been demonstrated directly. These transmembrane enzymes contain two catalytic domains. The C-terminal, intracellular domain exhibits similarity to members of glycosyltransferase family 5 (Coutinho et al., 2003), and probably uses UDP-glucose to produce a glucan chain. The $\mathrm{N}$-terminal, extracellular domain has resemblance to GH13 family enzymes and is thought to be involved in the coupling of extruded glucan chains (Grün et al., 2005; Hochstenbach et al., 1998). Two novel types of GH13 family homologues have recently been shown to play a role in fungal $\alpha$-glucan formation. The first of these is Aah3p, a glycosylphosphatidylinositol (GPI)-anchored protein identified in the fission yeast Schizosaccharomyces pombe (Morita et al., 2006). A knockout of the corresponding gene caused an aberrant cell shape and hypersensitivity towards cell wall-degrading enzymes, indicating a role for the Aah3p protein in cell wall integrity. The biochemical characterization of two homologous GPI-anchored proteins from A. niger (AgtA and AgtB) has revealed that they have 4- $\alpha$-glucanotransferase activity on maltooligosaccharides and starch (van der Kaaij et al., 2007). A second type of GH13 enzyme with a role in cell wall formation is Amylp from Histoplasma capsulatum, a close relative of the aspergilli (James et al., 2006). In this pathogenic, dimorphic fungus, $\alpha-(1,3)$-glucan is critical for virulence (Rappleye et al., 2004). A functional knockout strain of Amylp, a putative intracellular $\alpha$-amylase, completely loses the ability to form cell wall $\alpha$-(1,3)-glucan and has attenuated virulence (Marion et al., 2006). No biochemical characterization of Amylp has been reported, to our knowledge.

The recent publication of the genome sequences of four aspergilli (Machida et al., 2005; Pel et al., 2007; Nierman et al., 2005; Galagan et al., 2005) allowed the identification of all $\alpha$-amylase homologues in these species. In an initial analysis (Pel et al., 2007), it became apparent that these Aspergillus species encode several novel putative GH13 enzymes with relatively low similarity to the known extracellular fungal $\alpha$-amylases. Some of these proteins are, however, highly homologous to Amylp from $H$. capsulatum. In the present study, we have identified homologues of Amylp in aspergilli and other fungi, and performed sequence analysis as well as phylogenetic analyses on this group of novel fungal $\alpha$-amylases. This information is combined with the heterologous expression, purification and characterization of one of these enzymes, AmyD from A. niger, to gain a first-time insight into the biochemical properties of a representative of this group of novel fungal enzymes.

\section{METHODS}

Sequence retrieval and analysis. The full genome sequence of $A$. niger strain CBS 513.88 has been deposited at the EMBL database with accession numbers AM270980 a.m.270998 (Pel et al., 2007). Previously identified genes with locus tags An01g13610 (AmyD) and An09g03110 (AmyE) from this database were used as query sequences in BLAST searches (Altschul et al., 1997) in all nonredundant GenBank CDS translations, RefSeq Proteins, PDB and SWISS-PROT. The possible presence of a signal peptidase cleavage site or the possibility of non-classical secretion was analysed by using the web-based search tools SignalP and SecretomeP (http:// www.cbs.dtu.dk/services/) (Bendtsen et al., 2004, 2005).

Sequence alignment and evolutionary tree. A set of sequences encoding $\alpha$-amylases was retrieved from GenBank (Benson et al., 2006) and SWISS-PROT (Wu et al., 2006) (Table 1). The set was supplemented with the 12 fungal sequences identified as described above, and three additional sequences: Amylp from H. capsulatum (Marion et al., 2006), and AgtA (An09g03100) and AgtB (An12g02460) from A. niger. The alignment strategy was based on the approach described by Da Lage et al. (2004). In brief, (i) the best conserved regions, the $\beta 1, \beta 2, \beta 3, \beta 4, \beta 5, \beta 7$ and $\beta 8$ strands of the catalytic $(\beta / \alpha)_{8}$ barrel and region $\mathrm{V}$ of domain B (Janecek, 2002), were identified in each sequence; (ii) the segments preceding and succeeding the regions around strands $\beta 1$ and $\beta 8$, respectively, were cut off; (iii) the shortened sequences (amino acids 34-435 in AmyD) were aligned with the CLUSTAL w program (Thompson et al., 1994); (iv) the identified conserved sequence regions were aligned manually, if necessary; and ( $\mathrm{v}$ ) the remaining parts of the alignment (between the regions) were manually tuned where applicable. The evolutionary tree was calculated with the neighbour-joining method (Saitou \& Nei, 1987) implemented in the CLUSTAL $x$ package (Jeanmougin et al., 1998) using the final alignment including the gaps; the number of bootstrap trials used was 1000. The tree was displayed with the TreeView program (Page, 1996).

Strains, plasmids and cloning procedure. All basic molecular techniques were performed according to standard procedures (Sambrook et al., 1989). Escherichia coli TOP10 (Invitrogen) was used for transformation and amplification of recombinant DNA. E. coli BL21 STAR (DE3) (Invitrogen) was used for protein production. A synthetic gene with the coding sequence of An01g13610 was made by Geneart and cloned into pDONR221 using two ClaI restriction sites. The construct pDONR221-An01g13610 was subsequently used to make the final construct pDEST17-An01g13610 according to the manufacturer's instructions. All intermediate steps in the production of the construct were checked by restriction analysis, and the final construct was checked by sequencing (GATC Biotech). As a positive control for cloning and purification, and a negative control for enzyme activity assays, we also cloned the gene encoding 
Table 1. The GH13 family proteins used for the alignment and construction of the phylogenetic tree

\begin{tabular}{|c|c|c|c|c|}
\hline \multirow[t]{2}{*}{ Source } & Abbreviation & GenPept & Genome & GH13 \\
\hline & & \multicolumn{3}{|c|}{ accession number accession number subfamily } \\
\hline \multicolumn{5}{|l|}{ Bacteria } \\
\hline Actinoplanes sp. SE50 & Acpsp & CAC02970.1 & & Unassigned \\
\hline B. stearothermophilus & Bacst & AAA22235.2 & & 5 \\
\hline Bacillus subtilis & Bacsu & CAA23437.1 & & 28 \\
\hline E. coli $\mathrm{CFT} 073$ & Escco & AAN82828.1 & & 19 \\
\hline Pseudoalteromonas haloplanktis & Psaha & CAA41481.1 & & 15 \\
\hline Strep. mutans & Stcmu & AAC35010.1 & & 5 \\
\hline Streptomyces limosus & Stmli & AAA88554.1 & & 32 \\
\hline Thermoactinomyces vulgaris & Thavu & CAA49465.1 & & Unassigned \\
\hline Vibrio cholerae & Vibch & AAF96758.1 & & 19 \\
\hline Xanthomonas campestris & Xamca & AAA27591.1 & & 27 \\
\hline Saccharophagus degradans (bacterial-like) & SapdeB & ABD79837.1 & & 19 \\
\hline Saccharophagus degradans (plant-like) & SapdeP & ABD79827.1 & & 6 \\
\hline Saccharophagus degradans (animal-like) & SapdeA & ABD82195.1 & & Unassigned \\
\hline \multicolumn{5}{|l|}{ Archaea } \\
\hline Pyrococcus furiosus & Pycfu & AAB67705.1 & & 7 \\
\hline Thermococcus hydrothermalis & Thchy & AAC97877.1 & & 7 \\
\hline \multicolumn{5}{|l|}{ Fungi and yeasts (fam GH13_1) } \\
\hline A. niger (acid $\alpha$-amylase) & Aspni & $\begin{array}{c}\text { P56271 } \\
\text { (SWISS-PROT) }\end{array}$ & & 1 \\
\hline A. oryzae (TAKA-amylase) & Aspor & AAA32708.1 & & 1 \\
\hline Saccharomycopsis fibuligera & Samfi & CAA29233.1 & & 1 \\
\hline Cryptococcus sp. S-2 & Crcsp & BAA12010.1 & & 1 \\
\hline A. niger $\alpha$-glucanotransferase A & An-AgtA & CAK40249.1 & An09g03100 & 1 \\
\hline A. niger $\alpha$-glucanotransferase B & An-AgtB & CAK41088.1 & An12g02460 & 1 \\
\hline \multicolumn{5}{|l|}{ Fungi (fam GH13_5) } \\
\hline C. neoformans & Crcne & AAW44866.1 & CNG04200 & 5 \\
\hline H. capsulatum & Amylp & ABK62854.1 & & 5 \\
\hline A. niger & An-AmyD & CAK37367.1 & An01g13610 & 5 \\
\hline A. niger & An-AmyE & CAK40250.1 & An09g03110 & 5 \\
\hline A. nidulans & Aspnd & EAA63277.1 & AN3309.2 & 5 \\
\hline A. fumigatus & Aspfu & EAL90846.1 & Afulg15150 & 5 \\
\hline A. oryzae & Aspor1 & BAE56147.1 & AO090005001193 & 5 \\
\hline A. oryzae & Aspor2 & BAE58539.1 & AO090003001497 & 5 \\
\hline N. crassa & Neucr 1 & EEA30628.1 & NCU05873.1 & 5 \\
\hline N. crassa & Neucr2 & EAA33974.1 & NCU09486.1 & 5 \\
\hline M. grisea & Maggr1 & EAA51692.1 & MG03287.4 & 5 \\
\hline M. grisea & Maggr2 & EAA48105.1 & MG09642.4 & 5 \\
\hline M. grisea & Maggr3 & EAA48034.1 & MG09164.4 & 5 \\
\hline \multicolumn{5}{|l|}{ Plants } \\
\hline Hordeum vulgare (barley - high pI) & HorvuH & AAA98790.1 & & 6 \\
\hline Malus domestica (apple) & Maldo & AAF63239.1 & & 6 \\
\hline Phaseolus vulgaris (kidney bean) & Phavu & BAA33879.1 & & 6 \\
\hline \multicolumn{5}{|l|}{ Animals } \\
\hline Drosophila melanogaster (fruit fly) & Drome & CAA28238.1 & & 15 \\
\hline Homo sapiens (human, saliva) & Homsa & AAA52279.1 & & 24 \\
\hline Litopenaeus vannamei (white shrimp) & Penva & CAA54524.1 & & 24 \\
\hline
\end{tabular}

$\beta$-glucuronidase (gus) into pDEST-17 according to the manufacturer's instructions.

Protein production and purification. E. coli BL21 STAR (DE3) transformed with pDEST17-An01g13610 or pDEST17-gus was grown in LB medium (Ausubel et al., 1987) containing $100 \mu \mathrm{g}$ ampicillin $\mathrm{ml}^{-1}$ at $16{ }^{\circ} \mathrm{C}$ until an $\mathrm{OD}_{600}$ of 0.4 was reached. Expression was induced by the addition of $1 \mathrm{mM}$ IPTG and cultures were grown until $\mathrm{OD}_{600}$ was $0.8-1.0$. Cells were harvested by centrifugation (10 min, $5000 \mathrm{~g}, 4{ }^{\circ} \mathrm{C}$ ) and washed with $50 \mathrm{mM}$ Tris- $\mathrm{HCl}$ buffer ( $\mathrm{pH} 8$ ). Cell pellets were resuspended in binding buffer $(50 \mathrm{mM}$ Tris- $\mathrm{HCl}$ buffer, $\mathrm{pH}$ 8, containing $500 \mathrm{mM} \mathrm{NaCl}, 10 \mathrm{mM}$ imidazole and $5 \mathrm{mM} \beta$ mercaptoethanol). Cell-free extracts were produced by sonication of the resuspended cells $(8 \times 15 \mathrm{~s}$ with $40 \mathrm{~s}$ intervals, on ice) and 
subsequent centrifugation $\left(20 \mathrm{~min}, 4{ }^{\circ} \mathrm{C}, 10000 \mathrm{~g}\right.$ ). The cell lysate was applied to washed nickel-nitriloacetate (Ni-NTA) column material (Qiagen) and incubated for $2 \mathrm{~h}$ at $4{ }^{\circ} \mathrm{C}$. After washing the column material with binding buffer, His-tagged proteins were eluted with $50 \mathrm{mM}$ Tris- $\mathrm{HCl}$ buffer, $\mathrm{pH} \mathrm{8,} \mathrm{containing} 250 \mathrm{mM} \mathrm{NaCl}, 1 \mathrm{mM}$ $\beta$-mercaptoethanol and $100 \mathrm{mM}$ imidazole. At each stage of protein purification, the amount of protein was measured using the Bradford method with reagents from Bio-Rad, and purity was checked by SDSPAGE analysis (Laemmli, 1970). The enzyme was concentrated over a YM10 filter (Millipore) and stored at $-20{ }^{\circ} \mathrm{C}$ in Na-barbital buffer ( $\mathrm{pH}$ 6.5) containing $15 \%$ glycerol, v/v. Na-barbital buffer contained $28.5 \mathrm{mM}$ sodium acetate, $28.5 \mathrm{mM} \mathrm{Na}$-barbital and $116 \mathrm{mM} \mathrm{NaCl}$, and was brought to the desired $\mathrm{pH}$ by addition of $\mathrm{HCl}$. After Ni-NTA purification, AmyD was used in biochemical assays for a maximum of 4 days.

Analysis of enzyme activity. Substrates were obtained from SigmaAldrich, except for the following: nigerotriose was purchased from Dextra laboratories, nigerose was a kind gift from Nihon Shokuhin Kako, an $\alpha$-(1,3)-glucan isolated from Aspergillus nidulans was a kind gift from Dr B. J. Zonneveld (Leiden University) and a Lactobacillus reuteri exopolysaccharide (Kralj et al., 2004a) was supplied by Dr S. Kralj (University of Groningen). Starch, amylopectin and amylose type III (all from Sigma-Aldrich), used in activity assays, all originated from potato; glycogen originated from oysters.

The standard reaction conditions used to measure hydrolysing activity were as follows: the enzyme was incubated with $0.2 \%(\mathrm{w} / \mathrm{v})$ potato starch (or another substrate) in Na-barbital buffer ( $\mathrm{pH} 6.5)$ at $37{ }^{\circ} \mathrm{C}$. Reactions were performed in a total volume of $350 \mu$ l. Samples of $50 \mu \mathrm{l}$ were taken from the reaction every $3 \mathrm{~min}$, diluted in $50 \mu \mathrm{l}$ $\mathrm{Na}$-barbital buffer ( $\mathrm{pH}$ 6.5) and subsequently used for determination of reducing ends using the bicinchoninic acid method (Meeuwsen et al., 2000). Six samples were taken from each reaction and all reactions were performed at least in duplicate. The amount of enzyme added depended on the batch, but generally $1 \mu \mathrm{g}$ was added, representing between $2 \times 10^{-3}$ and $2.5 \times 10^{-3} \mathrm{U}$, with $1 \mathrm{U}$ defined as the amount of enzyme producing $1 \mu \mathrm{mol}$ reducing ends $\mathrm{min}^{-1}$. In all assays, reactions with $5 \mu \mathrm{g}$ Ni-NTA-purified Gus were included to check for background activity. Relative enzyme activities under different conditions were assayed with the same batch of enzyme. The $\mathrm{pH}$ optimum was determined by performing the standard reaction at $\mathrm{pH}$ values between 4 and 8.5 in Na-barbital buffer. Temperature stability of AmyD was determined using the standard test for starch hydrolysis, performed with enzyme diluted in $10 \mu \mathrm{l}$ Na-barbital, $\mathrm{pH} 6.5$, incubated for $10 \mathrm{~min}$ at different temperatures. The $K_{\mathrm{m}}$ value of AmyD for starch in the hydrolysis reaction was determined by measuring its activity with eight different concentrations of starch, varying between 0.01 and $1 \%(\mathrm{w} / \mathrm{v})$ under standard conditions in triplicate. The effect of $\mathrm{NaCl}$ was measured by addition of various concentrations of $\mathrm{NaCl}$ (between $50 \mathrm{mM}$ and $0.5 \mathrm{M}$ ) to the standard reaction. The hydrolysis of substrates other than potato starch was determined as described above. Appropriate calibration curves were included for every measurement.

Enzymic reactions for qualitative analysis were performed as follows. Standard reactions were performed in a total volume of $10 \mu \mathrm{l}$, containing $20 \mathrm{mM}$ disaccharide or oligosaccharide substrate, or $0.2 \%$ polysaccharide substrate, or a combination of these, in Na-barbital ( $\mathrm{pH}$ 6.5). Additional reactions with 100 or $500 \mathrm{mM}$ maltoheptaose were performed in the same way. AmyD enzyme $(1 \mu \mathrm{g})$ representing approximately $2 \times 10^{-3} \mathrm{U}$, or $5 \mu \mathrm{g}$ Ni-NTA-purified Gus, was added to the reaction mixture and incubated for $30 \mathrm{~min}$ at $37{ }^{\circ} \mathrm{C}$. A total of $2.4 \mu \mathrm{l}$ of reaction product was spotted on a TLC plate (Silica gel $60 \mathrm{~F}_{254}$, Merck) and after drying the plate was run for $6 \mathrm{~h}$ in a small amount of running buffer (butanol/ethanol/Milli-Q water, $5: 5: 3$, $\mathrm{v} / \mathrm{v})$. After running, the plate was dried and sprayed with
$50 \%$ sulphuric acid in methanol and developed for $10 \mathrm{~min}$ at $110{ }^{\circ} \mathrm{C}$.

Samples for HPLC (Dionex) analyses were prepared as follows. Reactions were performed in $1 \mathrm{ml} 1 \%$ amylopectin (w/v) or $1 \%$ amylose (w/v) in Na-barbital buffer ( $\mathrm{pH} 6.5)$ at $37^{\circ} \mathrm{C}$. AmyD enzyme $(2 \mu \mathrm{g})$, representing approximately $4 \times 10^{-3} \mathrm{U}$, or $10 \mu \mathrm{g}$ Ni-NTApurified Gus, was added to the reaction and samples $(250 \mu \mathrm{l})$ were taken after 0, 10 and 60 min of incubation. Samples were diluted in $1250 \mu \mathrm{l} 90 \%$ DMSO and subsequently used for HPLC analysis performed as described previously (Kralj et al., 2004b).

Activity staining of AmyD was performed by running $2 \mu \mathrm{g}$ Ni-NTApurified protein on SDS-PAGE gels containing $10 \%$ polyacrylamide and $0.12 \%(\mathrm{w} / \mathrm{v})$ amylopectin. The protein samples were not boiled and neither were denaturing components added to the loading buffer, so as to preserve enzymic activity. After separation, the gel was washed and incubated in Na-barbital buffer ( $\mathrm{pH} 6.5)$ at $37^{\circ} \mathrm{C}$ for $18 \mathrm{~h}$, and subsequently stained with diluted iodine solution. Iodine stains the amylopectin in the gel purple, except in places where it is degraded by $\alpha$-amylase activity. Subsequently, the gel was washed and used for the staining of $6 \times$ His-tagged proteins with the InVision staining method (Invitrogen) according to the manufacturer's instructions. Afterwards, the same gel was stained with Biosafe Coomassie and silver stain plus (both from Bio-Rad).

\section{RESULTS}

\section{Sequence retrieval and analysis}

Previous analysis of GH13 family enzymes encoded in the genome sequence of $A$. niger CBS 513.88 resulted in annotation of two predicted intracellular enzymes, An01g13610 (AmyD) and An01g13610 (AmyE), as novel $\alpha$-amylases, distantly related to extracellular fungal $\alpha$ amylases (Pel et al., 2007). A BLASTP search with these two sequences was performed in the available databases (during November 2006), yielding nine fungal homologues from Aspergillus oryzae, Aspergillus fumigatus, A. nidulans, Neurospora crassa and Magnaporthe grisea. A more distantly related homologous sequence from the genome of Cryptococcus neoformans (Loftus et al., 2005) was also included. This set of predicted proteins, combined with the A. niger AmyD and AmyE proteins and Amylp from $H$. capsulatum (Marion et al., 2006), was used for a detailed sequence comparison.

In A. niger, A. oryzae, A. nidulans and $M$. grisea, the genes encoding the Amylp homologues are part of a small cluster of genes which are predicted to be involved in production of cell wall $\alpha$-glucan. Apart from an Amylp homologue, these clusters contain genes encoding an $\alpha$-glucan synthase and a novel type of GPI-anchored GH13 family enzyme. A homologue of these GPI-anchored enzymes in S. pombe has recently been identified as important for cell wall $\alpha$-glucan synthesis (Morita et al., 2006). The retrieved protein sequences of seven out of the 12 Amylp homologues were missing one or more of the highly conserved regions specific to the GH13 family (Janecek, 2002; Kuriki \& Imanaka, 1999). After careful analysis of the original gene sequences, it appeared that the prediction of introns in these genes was not correct. The intron prediction was 
corrected in compliance with intron consensus elements (Kupfer et al., 2004), thereby restoring full-length protein sequences containing all conserved GH13 family residues and regions. In gene EEA30628.1 from N. crassa, the positions of two expected introns could not be predicted with certainty and thus no correction was made. Although the protein sequence was extended, it could nevertheless be used in alignments because no frameshift occurred within the sequence extensions. In A. oryzae BAE58539.1 the third conserved region could not be restored due to a frame shift, probably caused by a sequencing error. The sequence was nevertheless restored by detailed comparison with the homologous gene from another $A$. oryzae sequencing project (Uniprot accession number AB078784). None of the (corrected) protein sequences was predicted to have an $\mathrm{N}$-terminal signal for secretion. Two proteins were slightly above the threshold level in the analysis for non-classical secretion (EAA33974.1 and An09g03110).

The 13 (corrected) protein sequences together with two novel $\alpha$-glucanotransferases from A. niger (An-AgtA and An-AgtB) were aligned with $25 \alpha$-amylases from representative taxa of the three kingdoms of life: bacteria, archaea and eukarya. The alignment that spanned the entire catalytic $(\beta / \alpha)_{8}$ barrel, including domain $\mathrm{B}$ (the $\beta 3 \rightarrow \alpha 3$ insertion), was used for calculating the phylogenetic tree (Fig. 1). The tree clearly shows the high mutual similarity of the 13 novel GH13 proteins described in this study, and

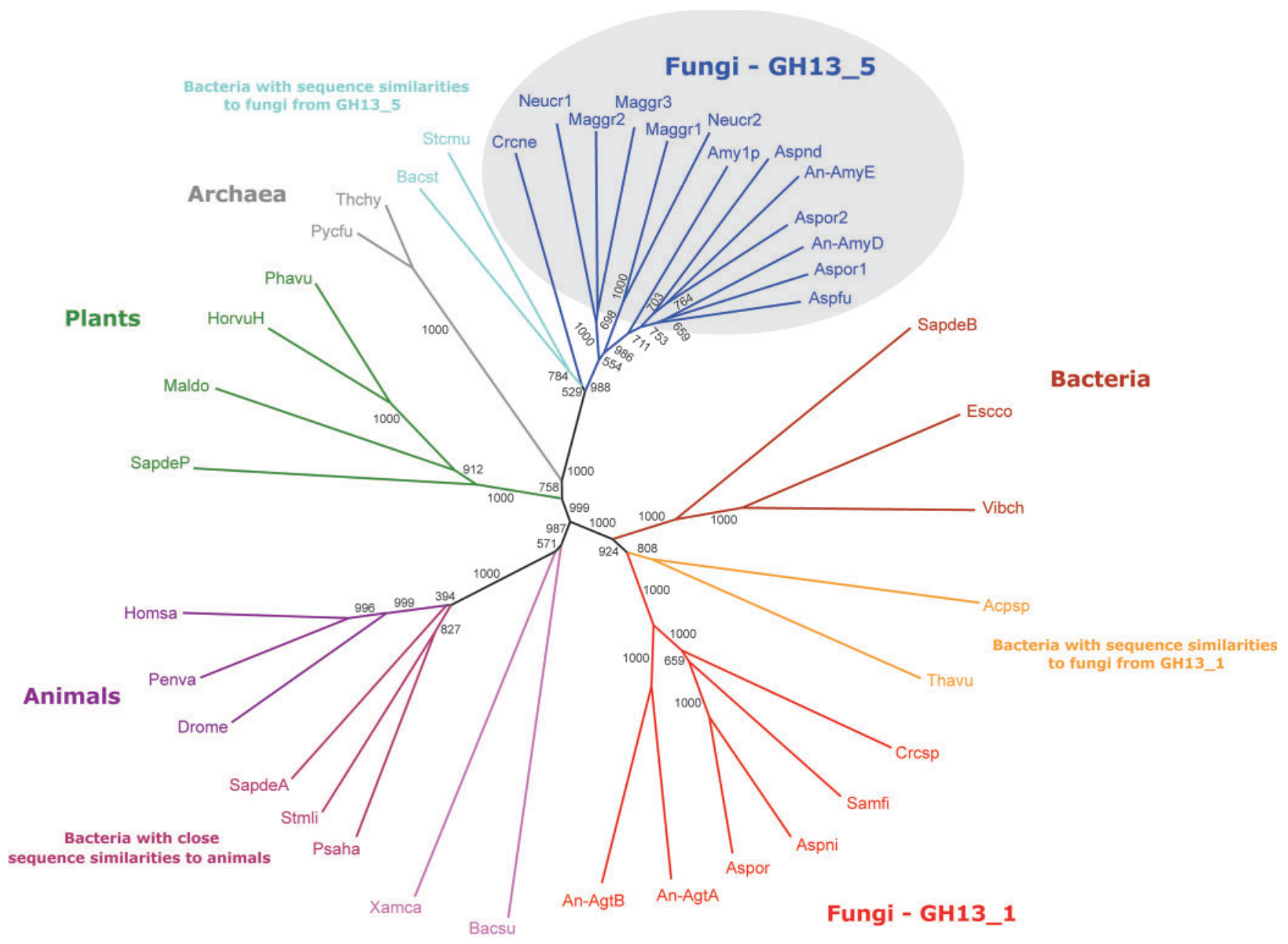

0.1

Bacteria with sequence similarities to animals

Fig. 1. Phylogenetic tree of GH13 family enzymes from a variety of organisms. The abbreviations used are defined in Table 1. The sources of the $\alpha$-amylase enzymes are indicated. The tree is based on the alignment made in CLUSTAL W of the part of the sequences encoding the $(\beta / \alpha)_{8}$ barrel. The two separate groups of fungal enzymes, intracellular (circled, GH13_5) and extracellular (GH13_1), are clearly distinguishable. The branch lengths are proportional to the sequence divergence. Numbers along branches are bootstrap values (1000 replicates). The scale bar (bottom-left corner) indicates 0.1 amino acid replacements per site. 
their high similarity to a group of bacterial $\alpha$-amylases of the liquefying type recently grouped in subfamily GH13_5, represented here by proteins from Bacillus stearothermophilus (Bacst in Fig. 1) and Streptococcus mutans (Stcmu) (Stam et al., 2006). For example, the similarity of AmyD to the bacterial proteins Bacst and Stcmu was $51-56 \%$, while its similarity to the archaeal proteins included was $33 \%$. Interestingly, a protein sequence from $C$. neoformans (Crcne), a basidiomycete, clustered between the GH13_5 proteins from ascomycete fungi and bacteria (Fig. 1). The 13 intracellular fungal proteins are clearly unrelated to all previously identified extracellular fungal $\alpha$-amylases grouped presently in subfamily GH13_1, represented by A. niger acid amylase (Aspni) and A. oryzae TAKA-amylase (Aspor). The recently identified $\alpha$-glucanotransferases AgtA and AgtB cluster with the extracellular fungal $\alpha$ amylases, rather than with the intracellular group. The bacterial $\alpha$-amylases form several clusters in the tree, reflecting their sequence similarities to enzymes from fungi, plants or animals, as described previously (Janecek, 1994; Janecek et al., 1999; Da Lage et al., 2004).

The 13 putative intracellular fungal $\alpha$-amylases share several sequence features with the bacterial enzymes in the GH13_5 family. These features are, or may be, invariant among the intracellular fungal enzymes and the related bacterial enzymes, but in most cases have no (conserved) equivalent in the other $\alpha$-amylases studied here (Fig. 2). These specific sequence features include: (i) histidine (His57, AmyD numbering) in the region flanking the strand $\beta 2$ from the $\mathrm{N}$ terminus; (ii) arginine (Arg60) and cysteine (Cys82) flanking strand $\beta 2$ at the $\mathrm{C}$ terminus, which, although occurring highly specifically in most fungal GH13_5 enzymes, are absent from the C. neoformans sequence representing the basidiomycete fungi; (iii) an almost invariant leucine residue preceding the con-

\begin{tabular}{|c|c|}
\hline SapdeB & $\begin{array}{c}\text { beta } 2 \\
\text { DIKGITQKIRSGYETALGVEVLWMTPVV }\end{array}$ \\
\hline Esceo & DLRGLTNKLD--YLQQLGVNALWISAPE \\
\hline Vibch & DLKGVIAKLD--HIQSLGTDAIWLSPIV \\
\hline Acpsp & DIQGVIDKLD--YIQGLGTTAIWLTPIE \\
\hline Thavu & DEQGIINRLD--YIKNMGETAIWITPVT \\
\hline Aspni & SWOGIINHLD--YIQGMGETAIWISPIT \\
\hline$\overline{\text { Aspor }}$ & TWQGIIDKLD--YIQGMGETAIWITPVT \\
\hline$\overline{\text { Crcsp }}$ & TEAGIIDKLD--YIQNMGETAIWISPVV \\
\hline Samfi & SEQGIIKKLD--YIKDMGETAIWISPVV \\
\hline$\overline{A n-A g} t A$ & TWRGMINHLD--YIQGMGEDAVMISPII \\
\hline$\overline{A n-A g t B}$ & SWQGTIDKLD--YIQGMGEDAIMISPVI \\
\hline$\overline{\text { Bacsu }}$ & ---TLKHNMK--DIHDAGYTAIQTSPIN \\
\hline Xanca & ---TVEARAK--QIADAGYRKVLVAPAY \\
\hline Stmli & ---SVARACTD-SLGPAGYGYVQVSPPQ \\
\hline Psaha & ---DVAQECEQ-YLGPKGYAAVQVSPPN \\
\hline SapdeA & ---DIASECEN-VLGPKGYAAVQVSPPQ \\
\hline Drome & ---DIAAECEN-ELGPNGYAGVQVSPVN \\
\hline Penva & ---DIAAECEN-ELGPRGEAGVQVSPPN \\
\hline Homsa & ---DIALECER-YLAPKGEGGVQVSPPN \\
\hline SapdeP & WYSVMQANVN--SIDNLGATHVWEAPVS \\
\hline Maldo & WWRNLETKVP--DIGRSGETSAWLPPAT \\
\hline HorvuH & WYNELMGKVD--DIAAAGITHVWLPPAS \\
\hline Phavu & WYNSLKNSVP--DIANAGITHVWLPPPS \\
\hline Pycfu & WWDHIRSKIP--EWYEAGISAIWLPPPS \\
\hline Thehy & WWDTIAQKIP--DWASAGISAIWIPPAS \\
\hline Bacst & LWTKVANEAN--NLSSLGITALWLPPAY \\
\hline Stamu & HWQHLAEDAS--HLKNIGISKVWMPPAE \\
\hline Crone & HWKKYESESE--RLANMGITACWIPPPT \\
\hline$\overline{\text { Neucr } 1}$ & HWRRLKIIP--TLAQLGITQIWIPPAC \\
\hline$\overline{\text { Maggr2 }}$ & MWRTADRIP--SLAALGVTDLWIPPAC \\
\hline$\overline{\text { Maggr3 }}$ & LINLIP--SLAPLGITKLWIPPAC \\
\hline$\overline{\text { Maggr1 }}$ & EKEIP--QLKSWGIDNIWVPPGC \\
\hline$\overline{\text { Neucr2 }}$ & SSQIP--QLSQHGISSLWIPPSC \\
\hline Amy1p & RAALP--SLKEIGVTSILLPPGC \\
\hline Aspnd & HWRRLSRALP--GLKAIGIDSVWLPPGC \\
\hline$\overline{A n-A m y E}$ & HWRLQHALP--AIHSLGVTS IWIPPGC \\
\hline Aspor2 & MWRTQHALP--GLKEIGIDNIWIPPGC \\
\hline An AmyD & RRLHQALP--NEKAIGVDNIWIPPGC \\
\hline Aspor1 & RLQRSLV--SLKSIGVDSIWIPPGC \\
\hline Aspfu & GWRLRH I LP--SLKEIGVDNIWIP PGC \\
\hline $\begin{array}{l}\text { Conservec } \\
\text { residues }\end{array}$ & H57 R60 \\
\hline
\end{tabular}

\begin{tabular}{|c|c|c|}
\hline beta 3 & beta 5 & beta 8 \\
\hline GIRVLADVI INH & FFMIGEVMH & GAVQIYYGDE \\
\hline GIRILFDVVMNH & EWMTGEANG & GAVQIFYGDE \\
\hline GIKILMDAVINH & EWMMGEVWG & GAIQVYYGDE \\
\hline GMKIYLDIVVNH & FFLFGEANS & GQPGGLLRAD \\
\hline GISVMLDVVANH & TETLGEVGH & GIPILYOGTE \\
\hline GMYLMVDVVENH & VYCVGEVDN & GIPIVYAGEE \\
\hline GMYLMVDVVANH & VYCIGEVLD & GIPIIYAGQE \\
\hline GMYLMVDVVVNH & MYMVGEVEN & GIPITYYGQE \\
\hline DMLLMVDIVTNH & VYSVGEVEQ & GIPVIYYGQE \\
\hline DMYLMMDTVINN & IFMTGEVLQ & GVPMIYQGQE \\
\hline GMYLLLDVVINN & GFMTGEVMD & GIPLVYQGLE \\
\hline GIKVIVDAVINH & EFQYGEILQ & GSTPLFFSRP \\
\hline GVETYADVVENH & VYVEGEVIT & GVPMVYTDNN \\
\hline GVKVVADSVINH & TYWKQEAIH & GSPDVHSGYE \\
\hline GVDIYVDTLINH & PVVEQEVID & GYPKVMSSYD \\
\hline GVDIYVDAVINH & PYIEQEVIG & GYPKVMSSYE \\
\hline GVRTYVDVVENH & AYIVQEVID & GTPRVMSSES \\
\hline GVRIYVDAVINH & PFIFQEVID & GYTRVMSSYY \\
\hline GVRIYVDAVINH & PEIYQEVID & GETRVMSSYR \\
\hline GIDSVADIVINH & -ECVGEVWT & GIPTVYWAHA \\
\hline KVRAMADIVINH & -FSVGEYNDD & GIPTVFYDHF \\
\hline GVKAIADIVINH & -FAVAEINT & GTPCIFYDHF \\
\hline GIKCLADIVINH & -EAVGEKND & GTPSIFYDHF \\
\hline GIKVIADVVINH & GWAVGEYTD & GQPVIEYRDF \\
\hline NMKVIADIVINH & GWAVGEYWD & GQPAIFYRDY \\
\hline GMQVYADVVEDH & LFTVGEYWS & GYPCVEYGDY \\
\hline EIMPISDIVINH & LYVFGEY & GIPCVFYGDY \\
\hline GIITYIDAVINH & AFCVGEF & GYPCVEYGDI \\
\hline GVSVLFDAVINH & WEIVGEY & WSDI \\
\hline GVGVL FDAVINH & WLLLGEY & $\mathrm{GT}$ \\
\hline GIEILFDAVINH & WFVVGE & \\
\hline GVGIYWDAVLNH & WFEVGEFWK & WWYGDI \\
\hline GVGLYWDAVINHH & WFLVGE & FYGDU \\
\hline EIRIIWDTVINH & WLLVAEYWK & YGDL \\
\hline GLGLIWDAVINH & FYIIGEYWT & \\
\hline GVGVLWDAVINH & VFVIGEYWS & YGDI \\
\hline GVGVYWDAVINH & LFVIGEYNS & \\
\hline GIGIYWDAVINH & YFIVGEYMK & IFYGDI \\
\hline GIGICWDAVINH & IFFVAEYWS & FYGDI \\
\hline GIGVHWDAVINH & FFVVSEYTR & GQPCI ENGDI \\
\hline L139 & Y/F/W298-299 & C395 \\
\hline
\end{tabular}

Fig. 2. Parts of the alignment of $\mathrm{GH} 13$ family $\alpha$-amylase proteins used for construction of the phylogenetic tree (Fig. 1 ) showing the amino acids specifically conserved among subfamily GH13_5. Abbreviations are defined in Table 1. Abbreviations for fungal proteins are underlined. 
served $\mathrm{NH}$ in conserved region $\mathrm{I}$, at the end of the $\beta 3$ strand region (136_DAVLNH); (iv) two aromatic residues succeeding the catalytic glutamate proton donor in conserved region III (around strand $\beta 5$ ) (297_EYWR); and (v) a cysteine and a leucine in the region covering the $\beta 8$ strand (392_GQPCIFWGDL), which are invariant in all fungal proteins but only partly conserved among the related bacterial sequences. In addition to the catalytic $(\beta / \alpha)_{8}$ barrel, domain B is also highly specific to the intracellular fungal enzymes and the bacterial enzymes in the GH13_5 family. With approximately 105 amino acids, this domain is longer than typically found in fungal $\alpha$-amylases in the GH13_1 family, with a B domain of around 65 amino acids.

\section{Biochemical properties of A. niger AmyD}

AmyD from A. niger, encoded by An01g13610, was overproduced, purified over Ni-NTA, and characterized to gain insights into the biochemical properties of the group of intracellular fungal $\alpha$-amylases. PCR with specific primers did not result in retrieval of amyD or amyC (An09g03110) cDNA from cDNA libraries constructed from A. niger strain N402 grown on starch or inulin (van der Kaaij et al., 2007). Therefore, a synthetic gene encoding the predicted coding sequence of An01g13610 was made, and codon usage was optimized for expression in E. coli. Production of AmyD in E. coli was only observed when the host was grown at $16-18{ }^{\circ} \mathrm{C}$, and the yield was relatively low (maximum yield $0.3 \mu \mathrm{g} \mathrm{ml}^{-1}$ ). The Ni-NTA-purified protein was incubated with starch, amylopectin and various di- and oligosaccharides to determine its enzymic activity. The main initial product formed from starch and amylopectin was maltotriose, followed by maltose and several larger maltooligosaccharides, mainly with a degree of polymerization (DP) of 6-9, as determined by HPLC analysis (Fig. 3). Maltooligosaccharides with a minimum length of five anhydroglucose units were hydrolysed, while no activity was observed on maltose, maltotriose and maltotetraose (Fig. 4). The specific activity on starch was $2.2 \pm 0.3 \mu \mathrm{mol}$ reducing ends $\mathrm{mg}^{-1} \mathrm{~min}^{-1}$. Starch-hydrolysing activity in the negative control, resulting from endogenous E. coli $\alpha$-amylase activity, was not detectable.

Proteins in the AmyD Ni-NTA-purified sample (calculated mass $63 \mathrm{kDa}$ ) and the control were separated by SDSPAGE and stained for the presence of $\alpha$-amylase activity and the $6 \times$ His tag (Fig. 5). No $\alpha$-amylase activity was detected in the control, while two activity spots were detected in the AmyD sample. These two activity bands were repeatedly co-purified upon Ni-NTA purification and subsequent anion-exchange purification (results not shown). The upper spot coincided with the main protein band obtained after Ni-NTA purification, which also stained for the $6 \times$ His-tag. The lower band apparently represented a differently folded, but more active form of the protein. The protein concentration in this spot was too low for detection with the InVision $6 \times$ His-tag staining method. It should be noted that the protein samples used for this SDS-PAGE were not denatured and therefore the size of the proteins cannot be derived directly from their position in relation to the marker proteins.

To check for activity towards substrates other than starch and maltooligosaccharides, AmyD was incubated with trehalose, sucrose, UDP-glucose, nigerose and nigerotriose, as sole substrates or in combination with starch or maltoheptaose. Analysis of the reactions by TLC revealed no reaction products other than those resulting from the hydrolysis of starch or maltoheptaose (results not shown). Additionally, to check whether AmyD was able to hydrolyse other bond types, the purified enzyme was incubated with dextran $[\alpha-(1,6)$ glycosidic bonds], A. nidulans $\alpha-(1,3)$-glucan, nigeran [a glucan with alternating $\alpha$-(1,3) and $\alpha$-(1,4) glycosidic bonds] and $L$.

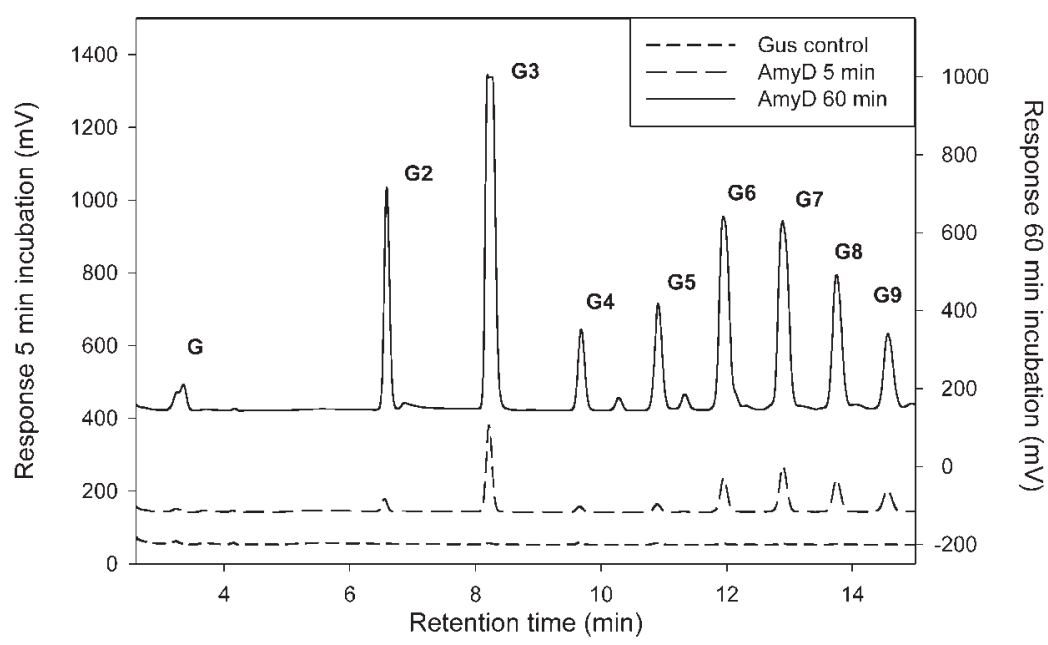

Fig. 3. HPLC (Dionex) analysis of the reaction products of the incubation of purified AmyD $\left(2 \mu \mathrm{g} \mathrm{ml}^{-1}\right)$ with $1 \%$ amylopectin. Samples were taken for analysis after 5 and 60 min of incubation at $37{ }^{\circ} \mathrm{C}$. The size of the maltooligosaccharide molecules represented by each peak is indicated (e.g. G, glucose, G2, maltose, etc.), and was assigned based on the retention times of defined maltooligosaccharides ranging from glucose to maltoheptaose. Both samples contained essentially the same reaction products: mainly maltotriose, followed by maltohexaose and maltoheptaose, and several other maltooligosaccharides at lower concentrations. No products were detected in the control reaction performed with Ni-NTA-purified $\beta$-glucuronidase $(10 \mu \mathrm{g}$ $\mathrm{ml}^{-1}$ ) and $1 \%$ amylopectin. 
(a)

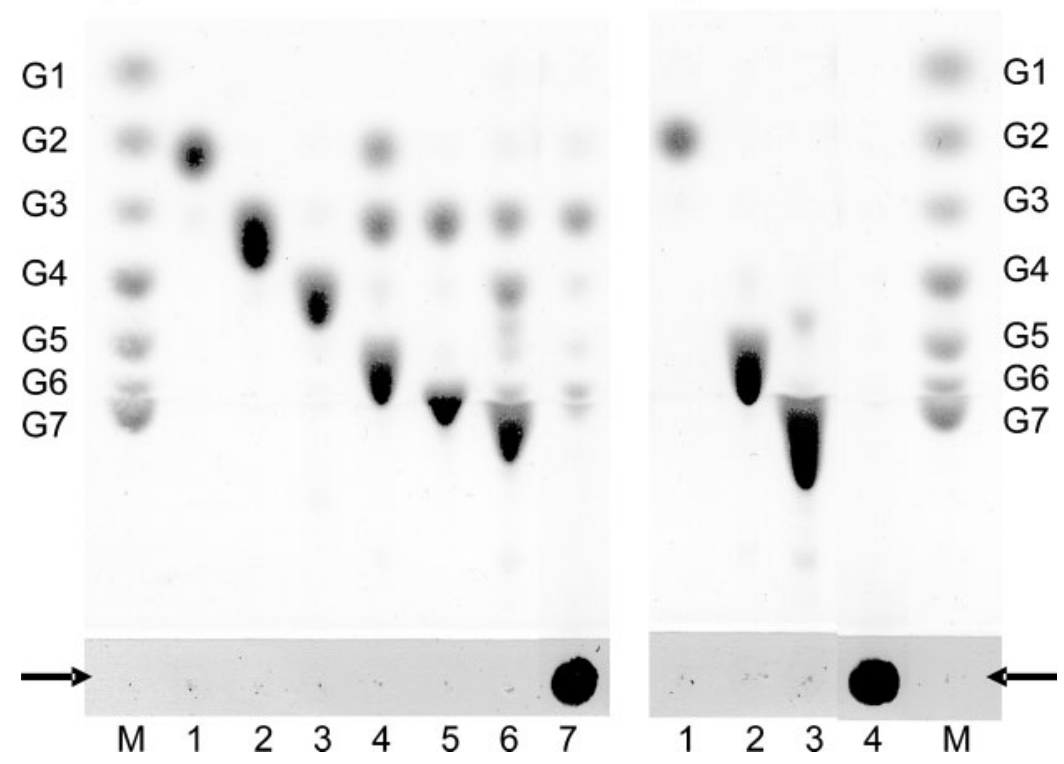

(b)

G1

G2

G3
Fig. 4. TLC analysis of the reaction products of $1 \mu \mathrm{g}$ AmyD incubated for $8 \mathrm{~h}$ with different maltooligosaccharides and starch. (a) Lanes: 1, maltose; 2, maltotriose; 3, maltotetraose; 4, maltopentaose; 5 , maltohexaose; 6 , maltoheptaose; 7, starch. (b) Control incubations performed with $5 \mu \mathrm{g} \beta$-glucuronidase for $8 \mathrm{~h}$ with maltose (1), maltopentaose (2), maltoheptaose (3) and starch (4). Marker (M) consisted of a mixture of maltooligosaccharides ranging from glucose (G1) to maltoheptaose (G7). Arrows indicate the spots where samples were loaded.

reuteri exopolysaccharide [containing $\alpha-(1,3)$ and $\alpha-(1,6)$ glycosidic bonds (Kralj et al., 2004a)]. None of these substrates was hydrolysed by AmyD.

The hydrolysis reaction of AmyD on starch and similar substrates was studied in more detail. This showed that AmyD was active towards starch and amylose, but had less activity towards amylopectin, and almost no activity towards glycogen (Table 2). The $K_{\mathrm{m}}$ for potato starch in the hydrolysis reaction was between 0.02 and $0.05 \%$ starch $(\mathrm{w} / \mathrm{v})$. Addition of $0.1,1$ or $10 \mathrm{mM} \mathrm{CaCl}_{2}$ or $1 \mathrm{mM}$ EDTA

(a)

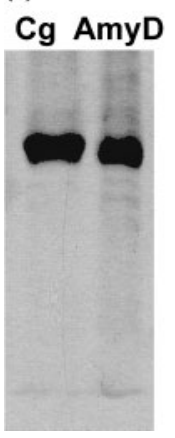

(b)

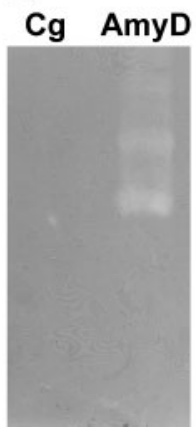

(c)

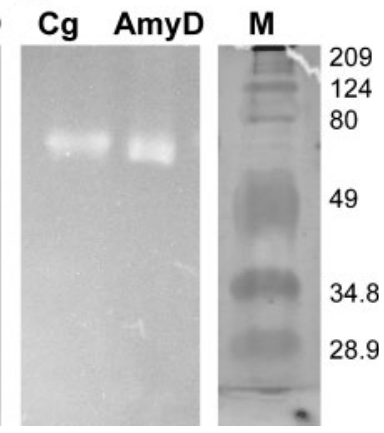

Fig. 5. SDS-PAGE analysis of AmyD. Ni-NTA-purified AmyD and $\beta$-glucuronidase serving as a control $(\mathrm{Cg})$ were separated by SDS-PAGE and stained for the presence of (a) proteins, using Biosafe Coomassie; (b) $\alpha$-amylase activity towards amylopectin, using iodine; and (c) a $6 \times$ His-tag, using the InVision staining method (Invitrogen). All staining procedures were performed with the same gel. The approximate sizes of the marker proteins are indicated in $\mathrm{kDa}$ next to the protein marker (M). did not have a significant effect on the rate of starch hydrolysis (Table 3). Analysis of hydrolysis at different $\mathrm{pH}$ values showed that the enzyme had a very broad $\mathrm{pH}$ optimum, with highly comparable activity in the range between pH 5 and 7.5, and a slight optimum between pH 5.5 and 6.5 (Fig. 6). Within this whole $\mathrm{pH}$ range, maltotriose was the dominant reaction product formed (results not shown). In the absence of substrate, stability of the enzyme at increased temperatures was rather poor: activity was lost rapidly at temperatures above $35{ }^{\circ} \mathrm{C}$ (Fig. 7). Addition of $1 \mathrm{mM} \mathrm{CaCl}_{2}$ did not have a significant effect on heat resistance. In the presence of substrate, however, the enzyme was much more stable, as there was no significant decrease of activity during the incubations with starch, measured at $37{ }^{\circ} \mathrm{C}$ over $15 \mathrm{~min}$. Addition of various amounts of $\mathrm{NaCl}$ had a negative effect on enzyme activity, leading to approximately $75 \%$ activity in the presence of $500 \mathrm{mM} \mathrm{NaCl}$, compared to the standard reaction conditions (Table 4 ).

Table 2. Relative hydrolytic activity of AmyD on different substrates

All reactions were performed with the same batch of purified enzyme and under standard conditions $(0.2 \%, \mathrm{w} / \mathrm{v}$, substrate concentration, $\mathrm{pH}$ 6.5). The $100 \%$ activity level was $2.2 \mathrm{U} \mathrm{mg}^{-1}$.

\begin{tabular}{|lc|}
\hline Substrate & Relative activity \\
\hline Potato starch & $100 \pm 2.6$ \\
Amylose & $101 \pm 4.2$ \\
Amylopectin & $66 \pm 2.6$ \\
Glycogen & $3.6 \pm 5.2$ \\
\hline
\end{tabular}


Table 3. Relative hydrolytic activity of AmyD in the presence of $\mathrm{Ca}^{2+}$ or EDTA

The $100 \%$ activity level was $2.2 \mathrm{U} \mathrm{mg}^{-1}$.

\begin{tabular}{|lc|}
\hline $\mathrm{Ca}^{2+}$ concn $(\mathbf{m M})$ & Relative activity \\
\hline 0 & $100 \pm 5.8$ \\
0.1 & $105 \pm 7.1$ \\
1 & $98.0 \pm 16.8$ \\
10 & $96.3 \pm 18.8$ \\
\hline EDTA concn $(\mathbf{m M})$ & \\
\hline 1 & $100.2 \pm 13.9$ \\
\hline
\end{tabular}

\section{DISCUSSION}

The recent release of the full genomic sequence of several fungal species has boosted research into various physiological processes in these organisms. Even in areas which have been relatively well studied, such as the degradation of starch, the information on novel sequences has raised many new questions. In the aspergilli, as first observed by Pel et al. (2007), a novel group of $\alpha$-amylases has been observed with very low similarity to all other fungal $\alpha$-amylases described thus far. Proteins belonging to this new fungal $\alpha$ amylase group characteristically have high mutual sequence similarity and a predicted intracellular location. According to the recent division of GH13 family enzymes into subfamilies, the extracellular fungal $\alpha$-amylases are classified into group GH13_1. We conclude that the novel intracellular fungal $\alpha$-amylases described here are members of subfamily GH13_5, displaying, within the frame of the entire $\alpha$-amylase GH13 family, the highest sequence similarity to the bacterial enzymes previously assigned to this subfamily (Stam et al., 2006). Their close evolutionary relationship was confirmed by the existence of several amino acids specifically conserved within this subfamily (Fig. 2). However, these did not include amino acids which are known to be predictive for certain enzyme reaction or product specificities within the GH13 family, such as hydrolysis of $\alpha$ - $(1,6)$ glycosidic bonds or $\alpha$-glucanotransferase activity (as reviewed by MacGregor et al., 2001). The specific functions of these conserved amino acid residues thus remain to be determined.

The 13 protein sequences subjected to sequence analysis in this paper can be considered to be examples of an undoubtedly much larger group of fungal $\alpha$-amylases. Homologous proteins have been identified in the genome sequences of the ascomycetes Botrytis cinerea, Chaetomium globosum and Sclerotinia sclerotiorum (http://www.broad. mit.edu/annotation/fungi/fgi/index.html). In many fungal species, the organization of the genes encoding the GH13_5 enzymes is highly conserved, strengthening the hypothesis that these enzymes have the same, or strongly related, physiological functions.

The phylogenetic analysis of the fungal sequences has shown that these $\alpha$-amylases are positioned on a common branch with a group of bacterial $\alpha$-amylases previously described as being related to plant $\alpha$-amylases (Da Lage et al., 2004). The similarity between the two groups implies an evolutionary relationship, as observed previously for a cluster of bacterial enzymes with similarity to animal $\alpha$ amylases, suggested to be a result of horizontal gene transfer (Da Lage et al., 2004). The bacterial $\alpha$-amylases belonging to subfamily GH13_5 include enzymes from Bacillus and Cytophaga species (Yuuki et al., 1985; Jeang et al., 2002; Kanai et al., 2004), some of which are thermostable (Kim et al., 2000) and used in industry (Guzman-Maldonado \& Paredes-Lopez, 1995). Several of these bacterial enzymes are known to produce oligosaccharides of specific lengths from starch, including, for example, a maltohexaose-forming $\alpha$-amylase from Bacillus (Kanai et al., 2004). To analyse whether similar properties are also encountered in the related fungal enzymes, we produced and characterized a randomly chosen homologue

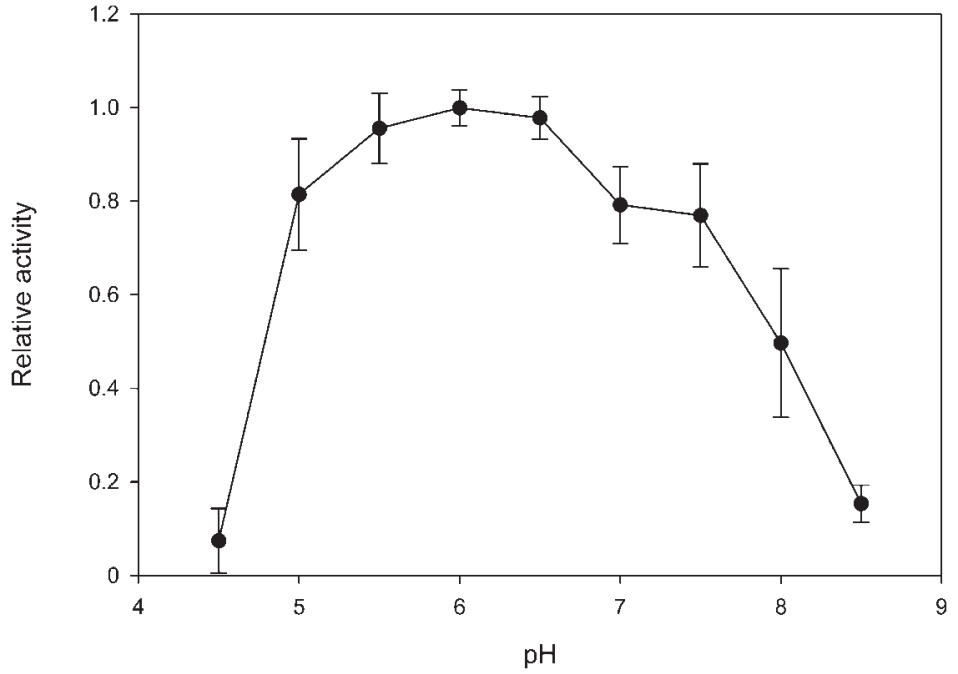

Fig. 6. Relative hydrolytic activity of AmyD on potato starch at different $\mathrm{pH}$ values. All reactions were performed in a broad-range $\mathrm{Na}$-barbital buffer in the presence of $0.2 \%(\mathrm{w} / \mathrm{v})$ potato starch. AmyD is active over a broad range of $\mathrm{pH}$ values, with an optimum between $\mathrm{pH} 5.5$ and 6.5 . 


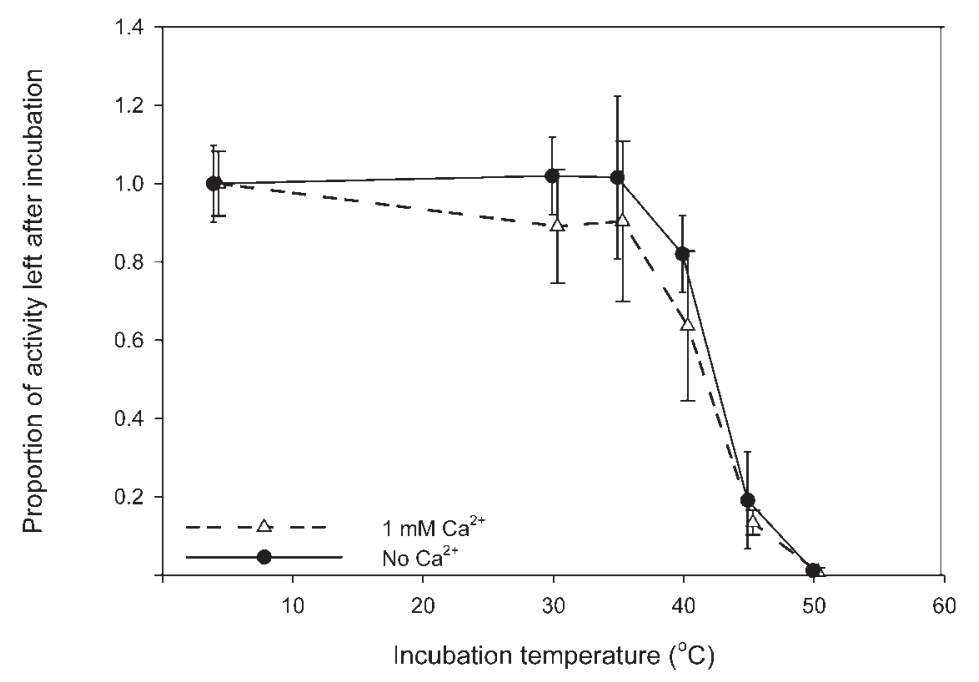

Fig. 7. Temperature stability of AmyD. The proportion of hydrolytic activity on starch remaining after incubation of AmyD at different temperatures for $10 \mathrm{~min}$, in the presence or absence of $1 \mathrm{mM} \mathrm{CaCl}_{2}$, is shown. Error bars (1SD) for the residual activity in the presence/ absence of $\mathrm{Ca}^{2+}$ are indicated.

from this cluster, AmyD from A. niger. The biochemical analysis showed that, like the related bacterial enzymes, AmyD mainly produces maltotriose from starch, amylose and amylopectin. Like other $\alpha$-amylases, AmyD displayed relatively low activity on highly branched substrates such as glycogen. Increased stability or activity in the presence of $\mathrm{Ca}^{2+}$, often encountered in $\alpha$-amylases (see e.g. Boel et al., 1990; Nielsen et al., 2003), was not observed for AmyD. In the 3D structure of bacterial GH13_5 family enzymes, a triad of metal ions $\left(\mathrm{Ca}^{2+}-\mathrm{Na}^{+}-\mathrm{Ca}^{2+}\right)$ has been observed between domain $\mathrm{A}$ and domain $\mathrm{B}$, and an additional $\mathrm{Ca}^{2+}$ ion has been located between domain A and domain C (Davies et al., 2005; Machius et al., 1998; Brzozowski et al., 2000). The amino acids interacting with these $\mathrm{Ca}^{2+}$ ions are only partly conserved among the fungal GH13_5 family enzymes; the presence of bound $\mathrm{Ca}^{2+}$ ions in these enzymes therefore appears less likely.

Ni-NTA-purified AmyD showed a maximum starchhydrolysing activity of $2.5 \mathrm{U} \mathrm{mg}^{-1}$, which is very low compared to the activity of extracellular fungal and bacterial $\alpha$-amylases, which commonly have a specific activity of 100-1000 $\mathrm{U} \mathrm{mg}^{-1}$ (see e.g. Khoo et al., 1994; Moreira et al., 2004; Dey et al., 2002). There are several possible explanations for this low activity of AmyD. First,

Table 4. Relative hydrolytic activity of AmyD in the presence of different concentrations of $\mathrm{NaCl}$

The $100 \%$ activity level was $2.4 \mathrm{U} \mathrm{mg}^{-1}$.

\begin{tabular}{|lc|}
\hline $\mathbf{N a C l}$ concn $(\mathbf{m M})$ & Relative activity \\
\hline 0 & $100 \pm 2.7$ \\
50 & $89.0 \pm 7.9$ \\
100 & $83.7 \pm 4.3$ \\
500 & $76.2 \pm 0.2$ \\
1000 & $74.3 \pm 2.9$ \\
\hline
\end{tabular}

the intracellular nature of the protein may mean that highly defined reaction conditions are needed for optimal activity. Several possibilities, such as the addition of salt or small amounts of yeast extract to supply potential cofactors, were tested, but these did not result in increased activity. Second, the substrates tested (starch and derived polymers) may not be the natural substrates for the intracellular AmyD enzyme. Although a variety of substrates with $\alpha$-glycosidic bonds were tested in different combinations, neither hydrolysis nor transglycosylation reactions were observed to occur on any of these substrates. Therefore, it appears likely that the observed hydrolysis of maltooligosaccharides is the natural reaction of AmyD. A third explanation is that a high AmyD activity is not needed for its physiological function in the cell. The data available on specific activities all relate to fungal $\alpha$-amylases acting in the extracellular environment. The latter enzymes have been selected for their ability to rapidly hydrolyse substrates, in order to minimize the chances for competing organisms to use the same carbon source. Therefore, a comparison of the activity levels of intra- and extracellular $\alpha$-amylase enzymes is not appropriate.

A possible physiological function for the fungal intracellular $\alpha$-amylases was provided by the study of the AmyD homologue Amylp of $H$. capsulatum. Although the enzymic activity of this protein has not been studied, a clear link was made with the production of cell wall $\alpha$ glucan, as a functional knockout was completely incapable of producing $\alpha$-(1,3)-glucan (Marion et al., 2006). This hypothesis regarding the function of fungal GH13_5 $\alpha$ amylases is strengthened by the genomic organization of the encoding genes, many of which are arranged in a small cluster of genes also encoding an $\alpha$-glucan synthase and a GPI-anchored $\alpha$-glucanotransferase. Such an arrangement of genes has been observed in A. niger amyE, for example, but not for $a m y D$, and for A. oryzae AO090003001497 but not for AO090005001193. Additionally, regulation of these $\alpha$-amylases by AmyR was not observed in $A$. niger nor in $A$. 
nidulans, contrary to what would have been expected for enzymes involved in starch degradation (X.-L. Yuan and others, unpublished results; Nakamura et al., 2006).

Recently, the first detailed structural analysis of fungal cell wall $\alpha$-glucan has been performed using $S$. pombe (Grün et al., 2005). On the basis of these data, the authors proposed a model which suggests that a small molecule consisting of $\alpha$-(1,4)-linked glucose residues acts as a primer for the formation of longer, $\alpha$-(1,3)-linked polymers by $\alpha$-glucan synthases. As proposed by Marion et al. (2006), the function of Amylp, AmyD and related proteins could be to produce such a primer molecule. In this study, we have shown that AmyD indeed produces small maltooligosaccharides, with a preference for maltotriose, in vitro. The combination of previously published data on Amylp, the genomic organization of fungal GH13_5 family genes, and the biochemical characterization of $A$. niger AmyD strongly suggest the involvement of these enzymes in cell wall $\alpha$-glucan formation. Further studies on the formation of cell wall $\alpha$-glucans in fungi, a process which is still relatively obscure, are needed to confirm this involvement and to determine the role of AmyD and other enzymes involved.

\section{ACKNOWLEDGEMENTS}

We are very grateful to Harrie Kools of Wageningen University for help with the HMMR searches and to Peter Sanders of TNO Quality of Life for the HPLC analysis. We thank DSM (The Netherlands) for providing the genome sequence of $A$. niger. R.v.d.K. was supported by SenterNovem in the framework of the IOP-Genomics programme (project IGE1021). S. J. thanks the Slovak Grant Agency for VEGA grant number 2/5067/27.

\section{REFERENCES}

Altschul, S. F., Madden, T. L., Schaffer, A. A., Zhang, J., Zhang, Z., Miller, W. \& Lipman, D. J. (1997). Gapped BLAST and PSI-BLAST: a new generation of protein database search programs. Nucleic Acids Res $\mathbf{2 5}$, 3389-3402.

Ausubel, F. M., Brent, R., Kingston, R. E., Moore, D. D., Seidman, J. G., Smith, J. A. \& Struhl, K. (1987). Current Protocols in Molecular Biology. New York: John Wiley \& Sons.

Barker, S. A. \& Carrington, T. R. (1953). Studies of Aspergillus niger. Part II. Transglycosylation by Aspergillus niger. J Chem Soc 1953 , 3588-3593.

Beauvais, A. \& Latgé, J. P. (2001). Membrane and cell wall targets in Aspergillus fumigatus. Drug Resist Updat 4, 38-49.

Bendtsen, J. D., Nielsen, H., Von Heijne, G. \& Brunak, S. (2004). Improved prediction of signal peptides: SignalP 3.0. J Mol Biol 340, 783-795.

Bendtsen, J. D., Kiemer, L., Fausboll, A. \& Brunak, S. (2005). Nonclassical protein secretion in bacteria. BMC Microbiol 5, 58.

Benson, D. A., Karsch-Mizrachi, I., Lipman, D. J., Ostell, J. \& Wheeler, D. L. (2006). GenBank. Nucleic Acids Res 34, D16-D20.

Boel, E., Brady, L., Brzozowski, A. M., Derewenda, Z., Dodson, G. G., Jensen, V. J., Petersen, S. B., Swift, H., Thim, L. \& Woldike, H. F. (1990). Calcium binding in $\alpha$-amylases: an X-ray diffraction study at
2.1- $\AA$ resolution of two enzymes from Aspergillus. Biochemistry 29, 6244-6249.

Brzozowski, A. M., Lawson, D. M., Turkenburg, J. P., BisgaardFrantzen, H., Svendsen, A., Borchert, T. V., Dauter, Z., Wilson, K. S. \& Davies, G. J. (2000). Structural analysis of a chimeric bacterial $\alpha$ amylase. High-resolution analysis of native and ligand complexes. Biochemistry 39, 9099-9107.

Coutinho, P. M., Deleury, E., Davies, G. J. \& Henrissat, B. (2003). An evolving hierarchical family classification for glycosyltransferases. $J$ Mol Biol 328, 307-317.

Da Lage, J. L., Feller, G. \& Janecek, S. (2004). Horizontal gene transfer from Eukarya to Bacteria and domain shuffling: the $\alpha$ amylase model. Cell Mol Life Sci 61, 97-109.

Davies, G. J., Brzozowski, A. M., Dauter, Z., Rasmussen, M. D., Borchert, T. V. \& Wilson, K. S. (2005). Structure of a Bacillus halmapalus family $13 \alpha$-amylase, BHA, in complex with an acarbosederived nonasaccharide at $2.1 \AA$ resolution. Acta Crystallogr D Biol Crystallogr 61, 190-193.

Dey, G., Palit, S., Banerjee, R. \& Maiti, B. R. (2002). Purification and characterization of maltooligosaccharide-forming amylase from Bacillus circulans GRS 313. J Ind Microbiol Biotechnol 28, 193-200.

Galagan, J. E., Calvo, S. E., Cuomo, C., Ma, L. J., Wortman, J. R., Batzoglou, S., Lee, S. I., Basturkmen, M., Spevak, C. C. \& other authors (2005). Sequencing of Aspergillus nidulans and comparative analysis with A. fumigatus and A. oryzae. Nature 438, 1105-1115.

Grün, C. H., Hochstenbach, F., Humbel, B. M., Verkleij, A. J., Sietsma, J. H., Klis, F. M., Kamerling, J. P. \& Vliegenthart, J. F. (2005). The structure of cell wall $\alpha$-glucan from fission yeast. Glycobiology 15, 245-257.

Guzman-Maldonado, H. \& Paredes-Lopez, O. (1995). Amylolytic enzymes and products derived from starch: a review. Crit Rev Food Sci Nutr 35, 373-403.

Henrissat, B. (1991). A classification of glycosyl hydrolases based on amino acid sequence similarities. Biochem J 280, 309-316.

Henrissat, B. \& Bairoch, A. (1996). Updating the sequence-based classification of glycosyl hydrolases. Biochem J 316, 695-696.

Hochstenbach, F., Klis, F. M., Van Den Ende, H., van Donselaar, E., Peters, P. J. \& Klausner, R. D. (1998). Identification of a putative alphaglucan synthase essential for cell wall construction and morphogenesis in fission yeast. Proc Natl Acad Sci U S A 95, 9161-9166.

James, T. Y., Kauff, F., Schoch, C. L., Matheny, P. B., Hofstetter, V., Cox, C. J., Celio, G., Gueidan, C., Fraker, E. \& other authors (2006). Reconstructing the early evolution of Fungi using a six-gene phylogeny. Nature 443, 818-822.

Janecek, S. (1994). Sequence similarities and evolutionary relationships of microbial, plant and animal $\alpha$-amylases. Eur J Biochem 224, 519-524.

Janecek, S. (1997). $\alpha$-Amylase family: molecular biology and evolution. Prog Biophys Mol Biol 67, 67-97.

Janecek, S. (2002). How many conserved sequence regions are there in the $\alpha$-amylase family? Biologia (Bratisl) 57 (Suppl. 11), 29-41.

Janecek, S., Leveque, E., Belarbi, A. \& Haye, B. (1999). Close evolutionary relatedness of $\alpha$-amylases from Archaea and plants. J Mol Evol 48, 421-426.

Jeang, C. L., Chen, L. S., Chen, M. Y. \& Shiau, R. J. (2002). Cloning of a gene encoding raw-starch-digesting amylase from a Cytophaga sp. and its expression in Escherichia coli. Appl Environ Microbiol 68, 3651-3654.

Jeanmougin, F., Thompson, J. D., Gouy, M., Higgins, D. G. \& Gibson, T. J. (1998). Multiple sequence alignment with CLUSTAL_X. Trends Biochem Sci 23, 403-405. 
Kanai, R., Haga, K., Akiba, T., Yamane, K. \& Harata, K. (2004). Biochemical and crystallographic analyses of maltohexaose-producing amylase from alkalophilic Bacillus sp. 707. Biochemistry 43, 1404714056.

Khoo, S. L., Amirul, A. A., Kamaruzaman, M., Nazalan, N. \& Azizan, M. N. (1994). Purification and characterization of $\alpha$-amylase from Aspergillus flavus. Folia Microbiol (Praha) 39, 392-398.

Kim, T. J., Park, C. S., Cho, H. Y., Cha, S. S., Kim, J. S., Lee, S. B., Moon, T. W., Kim, J. W., Oh, B. H. \& Park, K. H. (2000). Role of the glutamate 332 residue in the transglycosylation activity of Thermus maltogenic amylase. Biochemistry 39, 6773-6780.

Klis, F. M., Mol, P., Hellingwerf, K. \& Brul, S. (2002). Dynamics of cell wall structure in Saccharomyces cerevisiae. FEMS Microbiol Rev 26, 239-256.

Kralj, S., van Geel-Schutten, G. H., Dondorff, M. M., Kirsanovs, S., van der Maarel, M. J. \& Dijkhuizen, L. (2004a). Glucan synthesis in the genus Lactobacillus: isolation and characterization of glucansucrase genes, enzymes and glucan products from six different strains. Microbiology 150, 3681-3690.

Kralj, S., van Geel-Schutten, G. H., van der Maarel, M. J. \& Dijkhuizen, L. (2004b). Biochemical and molecular characterization of Lactobacillus reuteri 121 reuteransucrase. Microbiology 150, 2099-2112.

Kupfer, D. M., Drabenstot, S. D., Buchanan, K. L., Lai, H., Zhu, H., Dyer, D. W., Roe, B. A. \& Murphy, J. W. (2004). Introns and splicing elements of five diverse fungi. Eukaryot Cell 3, 1088-1100.

Kuriki, T. \& Imanaka, T. (1999). The concept of the $\alpha$-amylase family: structural similarity and common catalytic mechanism. J Biosci Bioeng 87, 557-565.

Laemmli, U. K. (1970). Cleavage of structural proteins during the assembly of the head of bacteriophage T4. Nature 227, 680-685.

Loftus, B. J., Fung, E., Roncaglia, P., Rowley, D., Amedeo, P., Bruno, D., Vamathevan, J., Miranda, M., Anderson, I. J. \& other authors (2005). The genome of the basidiomycetous yeast and human pathogen Cryptococcus neoformans. Science 307, 1321-1324.

MacGregor, E. A., Janecek, S. \& Svensson, B. (2001). Relationship of sequence and structure to specificity in the $\alpha$-amylase family of enzymes. Biochim Biophys Acta 1546, 1-20.

Machida, M., Asai, K., Sano, M., Tanaka, T., Kumagai, T., Terai, G., Kusumoto, K., Arima, T., Akita, O. \& other authors (2005). Genome sequencing and analysis of Aspergillus oryzae. Nature 438, 1157-1161.

Machius, M., Declerck, N., Huber, R. \& Wiegand, G. (1998). Activation of Bacillus licheniformis $\alpha$-amylase through a disorder $\rightarrow$ order transition of the substrate-binding site mediated by a calciumsodium-calcium metal triad. Structure 6, 281-292.

Machovic, M. \& Janecek, S. (2003). The invariant residues in the $\alpha$ amylase family: just the catalytic triad. Biologia (Bratisl) 58, 1127-1132.

Marion, C. L., Rappleye, C. A., Engle, J. T. \& Goldman, W. E. (2006). An $\alpha$-(1,4)-amylase is essential for $\alpha$-(1,3)-glucan production and virulence in Histoplasma capsulatum. Mol Microbiol 62, 970-983.

Matsuura, Y., Kusunoki, M., Harada, W. \& Kakudo, M. (1984). Structure and possible catalytic residues of Taka-amylase A. J Biochem (Tokyo) 95, 697-702.

Meeuwsen, P. J., Vincken, J. P., Beldman, G. \& Voragen, A. G. (2000). A universal assay for screening expression libraries for carbohydrases. J Biosci Bioeng 89, 107-109.

Moreira, F. G., Lenartovicz, V. \& Peralta, R. M. (2004). A thermostable maltose-tolerant $\alpha$-amylase from Aspergillus tamarii. J Basic Microbiol 44, 29-35.

Morita, T., Tanaka, N., Hosomi, A., Giga-Hama, Y. \& Takegawa, K. (2006). An $\alpha$-amylase homologue, aah3, encodes a GPI-anchored membrane protein required for cell wall integrity and morphogenesis in Schizosaccharomyces pombe. Biosci Biotechnol Biochem 70, 1454-1463.

Nakamura, A., Nishimura, I., Yokoyama, A., Lee, D. G., Hidaka, M., Masaki, H., Kimura, A., Chiba, S. \& Uozumi, T. (1997). Cloning and sequencing of an $\alpha$-glucosidase gene from Aspergillus niger and its expression in A. nidulans. J Biotechnol 53, 75-84.

Nakamura, T., Maeda, Y., Tanoue, N., Makita, T., Kato, M. \& Kobayashi, T. (2006). Expression profile of amylolytic genes in Aspergillus nidulans. Biosci Biotechnol Biochem 70, 2363-2370.

Nielsen, A. D., Fuglsang, C. C. \& Westh, P. (2003). Effect of calcium ions on the irreversible denaturation of a recombinant Bacillus halmapalus $\alpha$-amylase: a calorimetric investigation. Biochem J 373, 337-343.

Nierman, W. C., Pain, A., Anderson, M. J., Wortman, J. R., Kim, H. S., Arroyo, J., Berriman, M., Abe, K., Archer, D. B. \& other authors (2005). Genomic sequence of the pathogenic and allergenic filamentous fungus Aspergillus fumigatus. Nature 438, 1151-1156.

Page, R. D. M. (1996). TreeView: an application to display phylogenetic trees on personal computers. Comput Appl Biosci 12, 357-358.

Pel, H. J., de Winde, J. H., Archer, D. B., Dyer, P. S., Hofmann, G., Schaap, P. J., Turner, G., De Vries, R. P., Albang, R. \& other authors (2007). Genome sequencing and analysis of the versatile cell factory Aspergillus niger CBS 513.88. Nat Biotechnol 25, 221-231.

Petersen, K. L., Lehmbeck, J. \& Christensen, T. (1999). A new transcriptional activator for amylase genes in Aspergillus. Mol Gen Genet 262, 668-676.

Rappleye, C. A., Engle, J. T. \& Goldman, W. E. (2004). RNA interference in Histoplasma capsulatum demonstrates a role for $\alpha$ (1,3)-glucan in virulence. Mol Microbiol 53, 153-165.

Saitou, N. \& Nei, M. (1987). The neighbor-joining method: a new method for reconstructing phylogenetic trees. Mol Biol Evol 4, 406-425.

Sambrook, J., Fritsch, E. F. \& Maniatis, T. (1989). Molecular Cloning: a Laboratory Manual. Cold Spring Harbor, NY: Cold Spring Harbor Laboratory.

Stam, M. R., Danchin, E. G., Rancurel, C., Coutinho, P. M. \& Henrissat, B. (2006). Dividing the large glycoside hydrolase family 13 into subfamilies: towards improved functional annotations of $\alpha$ amylase-related proteins. Protein Eng Des Sel 19, 555-562.

Steyn, A. J., Marmur, J. \& Pretorius, I. S. (1995). Cloning, sequence analysis and expression in yeasts of a cDNA containing a Lipomyces kononenkoae $\alpha$-amylase-encoding gene. Gene 166, 65-71.

Tani, S., Katsuyama, Y., Hayashi, T., Suzuki, H., Kato, M., Gomi, K., Kobayashi, T. \& Tsukagoshi, N. (2001). Characterization of the amyR gene encoding a transcriptional activator for the amylase genes in Aspergillus nidulans. Curr Genet 39, 10-15.

Thompson, J. D., Higgins, D. G. \& Gibson, T. J. (1994). CLUSTAL W: improving the sensitivity of progressive multiple sequence alignment through sequence weighting, position-specific gap penalties and weight matrix choice. Nucleic Acids Res 22, 4673-4680.

van der Kaaij, R. M., Yuan, X. L., Franken, A., Ram, A. F. J., Punt, P. J., Maarel, M. J. E. C. \& Dijkhuizen, L. (2007). Characterization of two novel, putatively cell wall associated and GPI-anchored, $\alpha$-glucanotransferase enzymes of Aspergillus niger. Eukaryot Cell 6, 1178-1188.

Woranovicz-Barreira, S. M., Gorin, P. A., Sassaki, P. L., Marcelli, M. P. \& lacomini, M. (1999). Galactomannoglucans of lichenized fungi of Cladonia spp.: significance as chemotypes. FEMS Microbiol Lett 181, 313-317.

Wu, C. H., Apweiler, R., Bairoch, A., Natale, D. A., Barker, W. C., Boeckmann, B., Ferro, S., Gasteiger, E., Huang, H. \& other authors 
(2006). The Universal Protein Resource (UniProt): an expanding universe of protein information. Nucleic Acids Res 34, D187-D191.

Yuuki, T., Nomura, T., Tezuka, H., Tsuboi, A., Yamagata, H.,

Tsukagoshi, N. \& Udaka, S. (1985). Complete nucleotide sequence

of a gene coding for heat- and $\mathrm{pH}$-stable $\alpha$-amylase of Bacillus licheniformis: comparison of the amino acid sequences of three bacterial liquefying $\alpha$-amylases deduced from the DNA sequences. J Biochem (Tokyo) 98, 1147-1156.

Edited by: N. L. Glass 